\title{
Physiological and Structural Aspects of In Vitro Somatic Embryogenesis in Abies alba Mill
}

\author{
Terezia Salaj ${ }^{1, *}$, Katarina Klubicová ${ }^{1}$, Bart Panis ${ }^{2,3}$, Rony Swennen ${ }^{2,4} \mathbb{D}$ and Jan Salaj ${ }^{1}$ \\ 1 Plant Science and Biodiversity Center, Institute of Plant Genetics and Biotechnology, Akademicka 2, \\ 95007 Nitra, Slovakia; katarina.klubicova@savba.sk (K.K.); jan.salaj@savba.sk (J.S.) \\ 2 Laboratory of Tropical Crop Improvement, Faculty of Bioscience Engineering, KU Leuven, \\ Willem de Croylaan 42, 3001 Leuven, Belgium; b.panis@cgiar.org (B.P.); rony.swennen@kuleuven.be (R.S.) \\ 3 Alliance of Bioversity International and CIAT, c/o KU Leuven, Willem de Croylaan 42, 3001 Leuven, Belgium \\ 4 International Institute of Tropical Agriculture (IITA), C/o The Nelson Mandela African Institution of Science \\ and Technology (NM-AIST), P.O. Box, Arusha 447, Tanzania \\ * Correspondence: terezia.salaj@savba.sk
}

Received: 16 October 2020; Accepted: 13 November 2020; Published: 17 November 2020

\begin{abstract}
Initiation of somatic embryogenesis from immature zygotic embryos, long-term maintenance of embryogenic tissue in vitro or by cryopreservation, as well as maturation, of somatic embryos of Abies alba Mill. are reported in this study. For the initiation of embryogenic tissues, a DCR medium containing different types of cytokinins $\left(1 \mathrm{mg} \cdot \mathrm{L}^{-1}\right)$ were tested. During three consecutive years, 61 cell lines were initiated out of 1308 explants, with initiation frequencies ranging between 0.83 and $13.33 \%$. The type of cytokinin had no profound effect on the initiation frequency within one given year. Microscopic observations revealed presence of bipolar somatic embryos in all initiated embryogenic tissues. Besides the typical bipolar somatic embryos, huge polyembryonal complexes, as well as "twin" embryos, were observed. Maturation of somatic embryos occurred on a DCR medium supplemented by abscisic acid $\left(10 \mathrm{mg} \cdot \mathrm{L}^{-1}\right)$, polyethylene glycol (PEG-4000, 7.5\%) and 3\% maltose. The maturation capacity was cell-line dependent. All of the four tested cell lines produced cotyledonary somatic embryos, though at different quantities, of 16 to 252 per g of fresh weight. After germination, seedlings developed, but their further growth soon stopped after the formation of a resting bud. Altogether, seven cell lines were cryopreserved, using the slow-freezing technique. After rewarming, all tested cell lines showed regrowth rates between 81.8 and $100 \%$.
\end{abstract}

Keywords: cryopreservation; cytokinins; cytology; silver fir

\section{Introduction}

Somatic embryogenesis is the process of in vitro formation of embryos from somatic plants cells without fusion of gametes. Somatic embryogenesis from immature zygotic embryos in the conifer Norway spruce was first reported in 1985 [1,2]. Since then, considerable successes have been achieved, and efforts have been focused on the embryogenic tissue initiation, somatic embryo maturation and somatic seedlings regeneration in many conifers [3,4]. This process provides an experimental tool for the study of the early development of conifer trees, and this knowledge can be applied to zygotic embryos, since somatic embryos strongly resemble their zygotic counterparts in seeds [5]. Somatic embryogenesis in conifers also represents an efficient plant regeneration system important for genetic transformation studies and cryopreservation. In addition, production of embryos from somatic cells can be used for mass propagation of conifers, while the process is amenable to automation [6-8].

The members of the genus Abies represent valuable and economically important trees grown in various parts of the world. The micropropagation of Abies species by adventitious bud/shoot initiation 
and subsequent rooting resulted in limited success. Adventitious buds were initiated in Fraser fir [9], silver fir [10] or in hybrid firs [11], but the rooting of elongated shoots was poor. The application of somatic embryogenesis led to new opportunties for micropropagtion of Abies species, with a focus on the initiation of embryogenic tissues from immature or mature zygotic embryos. In Abies nordmanniana [12], A. lasiocarpa [13], A. cephalonica [14] or some Abies hybrids [15-18], embryogenic tissue was initiated from immature zygotic embryos. Other members of the genus, such as A. balsamea, A. fraseri and A. procera, proved to be more recalcitrant toward somatic embryogenesis [19]. Likewise, Rajbhandari and Stomp [20] reported only limited success with $A$. fraseri embryogenic tissue initiation and maintenance. Using a new medium containing $\mathrm{Al}$ salts, abscisic acid, brassinolide, paclobutrazol and sodium thiosulfate for the initiation of somatic embryogenesis in Fraser fir, Pullman et al. [21] succeeded in obtaining relatively high initiation frequencies (6-62\%, depending on the genotype), and $50 \%$ of initiations were captured on a maintenance medium. Cotyledonary somatic embryos capable of germination and somatic seedlings regeneration were obtained. The maturation of somatic embryos was genotype dependent and influenced by the salt composition in the medium. During maintenance, the maturation capacity of cell lines decreased. To resolve this problem, cryopreservation was applied.

Further experimentations focused on broadening the "initiation window" to mature zygotic embryos in A. nordmanniana [19,22], A. balsamea [23] and hybrid firs [24].

A first study on somatic embryogenesis in A. alba was reported by Erdelsky and Barancok [25]. They observed the initiation of rapidly proliferating white tissues; however, the embryogenic nature of the tissue was neither tested nor recognized. Gebhardt et al. [26] reported somatic embryogenesis from immature zygotic embryos of open pollinated seeds of $A$. alba. Similarly, in $A$. alba, the megagametophytes containing immature zygotic embryos produced tissue in which early stage somatic embryos have been identified. Some of these structures developed and formed cotyledons, while the differentiation of roots was suppressed [27]. Mature zygotic embryos of A. alba cultured on media with $2.2 \mu \mathrm{M}$ BA and $2.3 \mu \mathrm{M}$ kinetin (KIN) formed embryogenic suspensor masses at a $40 \%$ initiation frequency [28]. Initiation was induced only by cytokinins, but for further proliferation, $0.2 \mu \mathrm{M} 2,4-\mathrm{D}$ was also included. Zoglauer and Rheuter [10] described the early stages of A. alba somatic embryo differentiation at the structural level. The somatic embryos arose as single structures on explants, and their origin was traced to epidermal and subepidermal cells. Periclinal cell divisions resulted in formation of nodular structures isolated from surrounding tissues, indicating their autonomy. These structures have been recognized as early stage somatic embryos. Despite the many reports on the successful initiation and long-term maintenance on solid media or by cryopreservation, somatic embryo maturation, as well as somatic seedling regeneration, in A. alba remains problematic [29].

In this paper, we report the intiation of embryogenic tissues from immature zygotic embryos of A. alba Mill., using a DCR medium. The effect of five different cytokinins on the initiation was tested, and the maintenance of initiated tissue on solid media or by cryopreservation is reported. Cultivation of four different cell lines on a maturation medium resulted in the development of somatic embryos capable of germination and somatic seedling regeneration.

\section{Materials and Methods}

\subsection{Plant Material and Culture Conditions}

Green cones were collected from open pollinated trees of Abies alba Mill. growing in natural stands (Slovakia). The cones were harvested from different (3-5) trees in the second half of July as follows: July 24 in 2013, July 19 in 2017 and July 27 in 2019. Immature seeds, containing embryos at their early cotyledonary developmental stage, were extracted from the cones, and their surface was sterilized by immersion in $10 \% \mathrm{H}_{2} \mathrm{O}_{2}$, for ten min, followed by four rinses in sterile distilled water. The megagametophytes were aseptically excised from seeds and placed horizontally on the culture medium. 
For culture of explants, a DCR medium [30] containing enzymatic caseinhydrolysate $\left(1000 \mathrm{mg} \cdot \mathrm{L}^{-1}\right)$, glutamine (500 mg. $\left.\mathrm{L}^{-1}\right)$, myoinositol $\left(200 \mathrm{mg} \cdot \mathrm{L}^{-1}\right)$, glycine $\left(2 \mathrm{mg} \cdot \mathrm{L}^{-1}\right)$ and the vitamins thiamine $\left(1 \mathrm{mg} \cdot \mathrm{L}^{-1}\right)$, nicotinic acid $\left(0.5 \mathrm{mg} \cdot \mathrm{L}^{-1}\right)$, pyridoxine $\left(0.5 \mathrm{mg} \cdot \mathrm{L}^{-1}\right)$ and $2 \%$ sucrose was used. The medium was further supplemented with cytokinins N6-benzyladenine (BA), zeatin (ZEA), thidiazuron (TDZ), kinetin (KIN) or 2-isopentenyladenine (2iP) at a concentration of $1 \mathrm{mg} \cdot \mathrm{L}^{-1}$. The medium was solidified with gelrite $0.3 \%$ (Duchefa).

The megagametophytes were placed on the surface of a medium in plastic Petri plates (diameter $6 \mathrm{~cm}$ ). In each dish, 6 explants were cultured, in the dark, at $23^{\circ} \mathrm{C}$. Following initiation, the embryogenic tissue was maintained by transfers to new media at two-to-three-week intervals. For the initiation experiments, a total of 1308 explants were used. During the first 6 months, the cultures were maintained on the same initiation medium. Thereafter, they were transferred to a DCR medium supplemented with $1 \mathrm{mg} \cdot \mathrm{L}^{-1} \mathrm{BA}$. Initiation frequencies (IF) were calculated as the number of explants that produced embryogenic tissues relative to the total number of cultured explants.

\subsection{Microscopic Observations}

The structure of early somatic embryos in tissue was followed by using squash preparations. Small pieces of tissues were placed on glass slide, stained with two drops of $2 \%$ acetocarmine for two to three min, squashed and covered by a cover glass. The preparations were examined under a light microscope Axioplan 2 (Carl Zeiss Microscopy) equipped with a camera system (Sony DXC-5500).

First observations were executed when the initiated tissue was already intensively proliferating and later at two-to-three-month intervals, regularly, during the maintenance. For each observation, at least three samples were used per cell line.

\subsection{Fresh and Dry Mass Accumulation}

At day 8 after the last subculture, $0.5 \mathrm{~g}$ of tissue was transferred to a DCR proliferation medium. The fresh and dry mass were evaluated at days 7, 14 and 21 after transfer. The tissues were taken from the proliferation medium, and their fresh mass was recorded. The samples were then dried in an oven, for $3 \mathrm{~h}$, at $80^{\circ} \mathrm{C}$, following $2 \mathrm{~h}$ at $105^{\circ} \mathrm{C}$, and the dry mass was recorded. Then, the samples were dried at $105^{\circ} \mathrm{C}$, for $2 \mathrm{~h}$, and dry mass again recorded. The two measurements were compared, and the second measurement was considered in case it did not differ from the first one by more than $1 \mathrm{mg}$. Nine cell lines were included in the experiments that were repeated twice, with 5 samples for each cell line. The obtained data were analyzed by using a $t$-test.

\subsection{Somatic Embryo Maturation and Germination}

For the maturation experiments four cell lines were selected (A01, A30, A31 and A32). On day 12 after the last subculture, $1 \mathrm{~g}$ of vigorously growing tissue was resuspended in a liquid medium containig half the strength of DCR macro- and microelements, and an aliquot of $100 \mathrm{mg}$ of fresh mass was then pipetted and spread onto the stacked filter paper discs, for the liquid to be absorbed. The upper filter paper disc was placed on the maturation medium that consisted of DCR macro-and microelements, $10 \mathrm{mg} \cdot \mathrm{L}^{-1}$ abscisic acid (ABA) and supplemented with $7.5 \%$ polyethylene glycol (PEG-4000) and 3\% maltose and solidified with gelrite (0.3\%). The maturation of cell lines was also tested on a medium without PEG-4000 of the same composition as indicated above. The cultures were kept in a culture room, in darkness, at $23^{\circ} \mathrm{C}$. After eight weeks of cultivation, the developing somatic embryos were transferred to a medium devoid of ABA and PEG-4000 (post-maturation treatment, two to three weeks). The developing somatic embryos were categorized according to von Arnold and Hakman [31] as Stage 2 (precotyledonary somatic embryos), Stage 3 (cotyledonary somatic embryos) and Stage 4 somatic seedlings. The number of developing somatic embryos (Stages 2 and 3) was calculated on $1 \mathrm{~g}$ of fresh mass. The number of precotyledonary embryo was calculated after five weeks of cultivation on a maturation medium. The number of cotyledonary embryos was evaluated after eight weeks, on a maturation medium. The data were analyzed by using a $t$-test. 
The maturation experiments were repeated three times, with each four to five Petri dishes. After post-maturation treatment, the somatic embryos on the filter paper discs were transferred to empty Petri dishes that were $6 \mathrm{~cm}$ in diameter and placed into Nalgene ${ }^{\mathrm{TM}}$ container with sterile distilled water on the bottom, for two weeks, in darkness, at $23^{\circ} \mathrm{C}$. For germination, well-developed cotyledonary embryos that consisted of at least four cotyledons were selected. The germination was evaluated by the $t$-test. The germination medium contained DCR macro and microelements, $2 \%$ maltose and $1 \%$ activated charcoal and was solidified with $0.5 \%$ gelrite. During the first week of germination, Petri dishes with somatic embryos were kept in darkness; the second week, the somatic embryos were cultured in dimmed light, and, finally, when elongation of hypocotyl and cotyledons occurred, the somatic embryos, which were already small plantlets, were transferred to light. Lastly the small plantlets were transferred into Magenta baby-food jars on the same medium as for germination and cultured in a growth chamber room, at $23^{\circ} \mathrm{C}$, at a $16 \mathrm{~h}$ photoperiod, under cool white fluorescent tubes, at a photosynthetic photon flux density of $50 \mu \mathrm{mol}^{-2} \mathrm{~s}^{-1}$.

\subsection{Cryopreservation}

For cryopreservation, the two-step slow-freezing technique was applied as described elsewhere in detail [32,33]. Briefly explained, $1.5 \mathrm{~g}$ of vigorously growing tissue of the cell lines A01, A02, A07, A11, A13, A16 and A23 was precultured on a solid DCR proliferation medium containing $0.5 \mathrm{M}$ sorbitol, for $24 \mathrm{~h}$. Then, $3 \mathrm{~g}$ of tissue collected from two plates was resuspended in a liquid medium of the same composition as the preculture medium. Thereafter, a 10\% DMSO (dimethylsulfoxid) solution dissolved in a proliferation medium was added, in three steps, on ice, to reach a final concentration of $5 \%$ DMSO. The suspension was pipetted to $1.8 \mathrm{ml}$ cyrovials, and the cryovials were placed to Mr. Frosty (Nalgene ${ }^{\mathrm{TM}}$ ) container filled with isopropanol. The container with samples was put into the deep freezer, at $-80^{\circ} \mathrm{C}$. The temperature was measured by placing a thermocouple in a representative cryovial, and when $-40^{\circ} \mathrm{C}$ was reached, the cryovials were plunged into liquid nitrogen (LN) and kept in this condition for one year. Then the vials were rewarmed in a $40^{\circ} \mathrm{C}$ water bath, for the cells to be cultured on the proliferation medium. Samples designated as control (C) were preteated but not exposed to liquid nitrogen. Visual observations were executed at 3-5-day intervals, to monitor the tissue regrowth. The experiments were repeated three times; one repetition included five Petri dishes for each cell line, as control, as well as cryopreserved tissue.

\section{Results}

\subsection{Initiation Experiment in 2013}

The embryogenic tissue was initiated from female gametophytes containing immature zygotic embyos. Then, 12-15 days after placing immature zygotic embyos on initiation media, white embryogenic tissues were observed, protruding from explants (Figure 1a). Twenty-five out of the 312 cultured explants, i.e., $8.03 \%$, produced embryogenic tissue. The frequency of embryogenic tissue formation was not profoundly affected by the type of cytokinin used (Table 1). ZEA was the most effective, with $13.33 \%$ initiation frequency. Treatments with BAP or KIN gave lower initiation frequencies, but the results with respect to the PGR treatment were statistically not significant $(p \leq 0.05)$. Once a size of approximately $5 \mathrm{~mm}$ was reached, the embryogenic tissue was separated from the explant and subcultured as a cell line, derived from an individual zygotic embryo.

All of the established cell lines proliferated intensively over one year. Subsequently, four out of the 25 cell lines started to show signs of necrosis, and, in the second year of cultivation, some cell lines changed the mucilaginous consistency, resembling non-embryogenic callus tissue. 

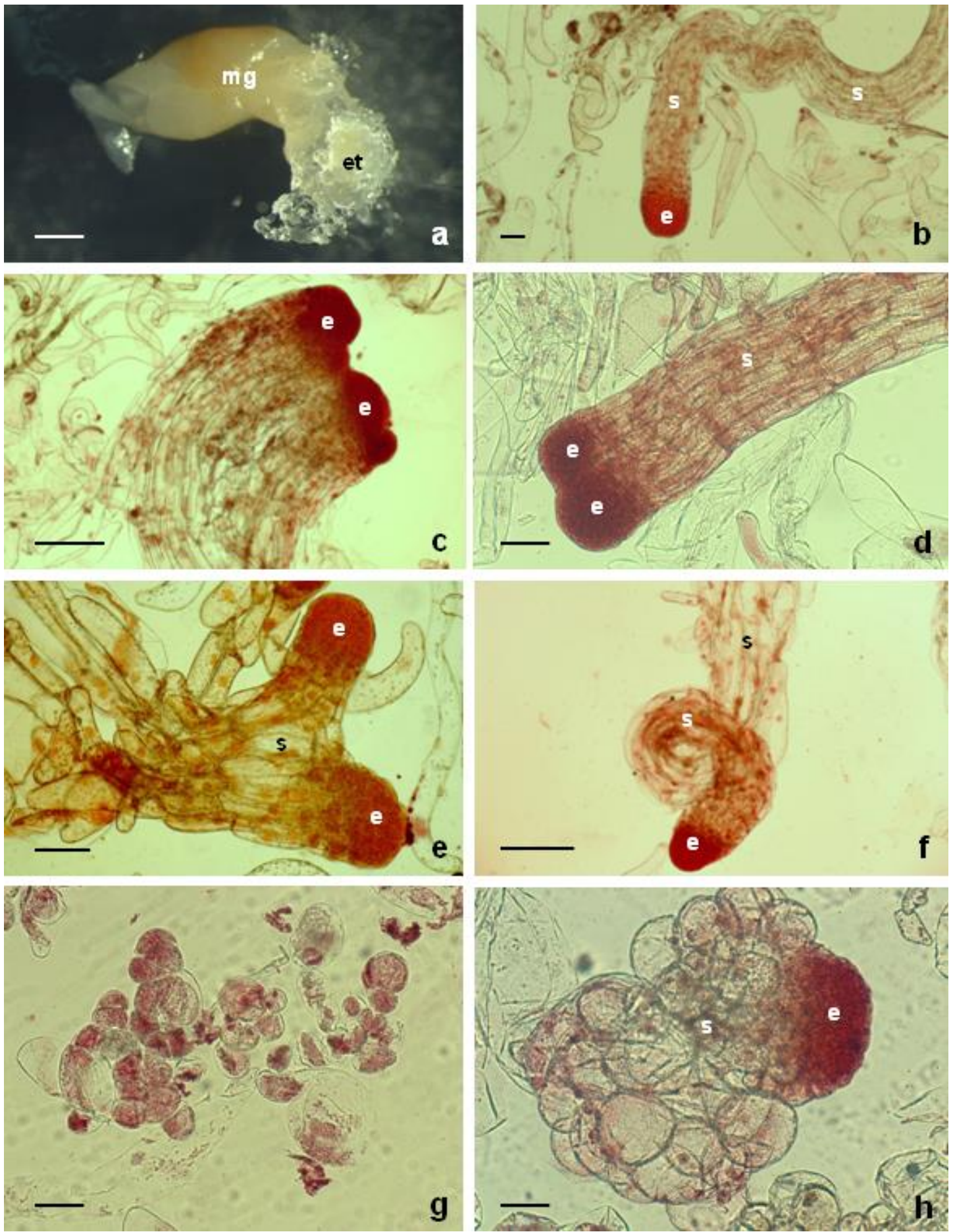

Figure 1. Initiation of somatic embryogenesis and structural characterization of embryogenic tissue in Abies alba: (a) extrusion of embryogenic tissue (et) from megagametophyte explant (mg), (b) bipolar somatic embryo with embryonal meristematic cells (e) and long vacuolized suspensor cells (s), (c) polyembryonal complex observable in embryogenic tissue, (d) twin somatic embryo, (e) somatic embryos with branched suspensor (s), (f) curling of suspensor (s) of a somatic embryo; (g) unorganized cell mass observed in tissue that lost the embryogenic character, (h) somatic embryo with changed micromorphology after five years of maintenance on a proliferation medium. Bars: a-1000 $\mu \mathrm{m}$; (b,d,e,g,h) $200 \mu \mathrm{m} ;(\mathbf{c}, \mathbf{f}) 500 \mu \mathrm{m}$. 
Table 1. Initiation of embryogenic tissues from immature zygotic embryos of Abies alba Mill., in three years, and the effect of different cytokinins (CKs) in the initiation medium.

\begin{tabular}{|c|c|c|c|c|c|c|c|c|c|}
\hline & \multicolumn{3}{|c|}{2013} & \multicolumn{3}{|c|}{2017} & \multicolumn{3}{|c|}{2019} \\
\hline & Explant No. & RE & IF (\%) ${ }^{1}$ & Explant No. & RE & IF (\%) ${ }^{1}$ & Explant No. & RE & IF (\%) ${ }^{1}$ \\
\hline \multicolumn{10}{|l|}{ CKs } \\
\hline BA & 60 & 4 & $\begin{array}{c}6.66 \\
(3.69)\end{array}$ & 114 & 1 & $\begin{array}{c}0.88 \\
(0.87)\end{array}$ & 72 & 6 & $\begin{array}{c}8.33 \\
(3.24)\end{array}$ \\
\hline ZEA & 60 & 8 & $\begin{array}{l}13.33 \\
(4.84)\end{array}$ & 120 & 1 & $\begin{array}{c}0.83 \\
(0.32)\end{array}$ & 90 & 6 & $\begin{array}{c}6.67 \\
(3.17)\end{array}$ \\
\hline TDZ & 60 & 3 & $\begin{array}{c}5.0 \\
(3.55) \\
\end{array}$ & 120 & 2 & $\begin{array}{c}1.67 \\
(0.47) \\
\end{array}$ & 78 & 7 & $\begin{array}{c}8.97 \\
(3.05) \\
\end{array}$ \\
\hline KIN & 66 & 7 & $\begin{array}{c}10.6 \\
(4.64)\end{array}$ & 114 & 2 & $\begin{array}{c}1.75 \\
(1.21)\end{array}$ & 78 & 6 & $\begin{array}{c}7.69 \\
(3.07)\end{array}$ \\
\hline $2 \mathrm{iP}$ & 66 & 3 & $\begin{array}{c}4.54 \\
(7.42)\end{array}$ & 120 & 2 & $\begin{array}{c}1.67 \\
(0.47)\end{array}$ & 90 & 3 & $\begin{array}{c}3.33 \\
(1.78)\end{array}$ \\
\hline Average & & & $\begin{array}{c}8.03 \\
(1.66)\end{array}$ & & & $\begin{array}{c}1.36 \\
(0.21)\end{array}$ & & & $\begin{array}{c}6.99 \\
(0.99)\end{array}$ \\
\hline
\end{tabular}

IF-initiation frequency. RE-responding explants. ${ }^{1}$ Standard errors of mean are in parenthesis. BA-N6-benzyladenine; ZEA—zeatin; TDZ—-thidiazuron; KIN—kinetin; 2iP-2-isopentenyladenine.

\subsection{Initiation Experiment in 2017}

The initiation frequencies were lower than in 2013, giving very low values, ranging from 0.83 to 1.75 , averaging $1.36 \%$ (Table 1). Altogether, eight cell lines were initiated from a total 588 of explants, five died shortly after initiation and the remaining three cell lines were maintained on a proliferation medium (A30, A31 and A32). The effect of different types of cytokinins was again not apparent.

\subsection{Initiation Experiment in 2019}

In that year, the megagametophyte explants gave rise to embryogenic tissue at an overall rate of $6.99 \%$. Altogether, 28 cell lines were obtained from 408 cultured explants (Table 1). After more than one year of maintenance, 18 cell lines were well proliferating. The extrusion of embryogenic tissue occurred within the first two to three weeks of explant culture. The ability to produce embryogenic tissue was not dependent on the type of cytokinin used.

\subsection{Overall Assesment of Initiation}

In the experiments performed over three consecutive years, 1308 explants were plated on a culture medium, and, altogether, 61 embryogenic cell lines were initiated. Our results suggest that the used cytokinins were equally efficient in their induction capacity.

\subsection{Structural Organization of Embryogenic Tissue}

The cellular composition of the different cell lines (tissue) was variable. Bipolar somatic embryos, composed of meristematic embryonal part ("head") subtended by a long suspensor, were observed in most of proliferating tissues (Figure 1b). Besides these structures, huge polyembryonal complexes (Figure 1c) or "twin" embryos (Figure 1d) could be observed. In these structures, two or several meristematic "heads" joined sharing a common suspensor. Occasionally the long suspensor branched or coiled (Figure 1e,f). Additionally, meristematic cell clumps interspersed with long vacuolized cells containing an apparent nucleus were frequently observed.

\subsection{Changes in Structural Organization during Proliferation}

Some cell lines lost embryogenic features in time, showing a consistence of non-embryogenic hard callusses. In these cell lines, the typical bipolarity of somatic embryos dissappeared, and round-shaped cells became apparent (Figure 1g). During the first five years of maintenance, cell line A01 was 
characterized by the presence of bipolar somatic embryos. After this period, structural changes occurred. The meristematic "heads" were still present, but the long suspensor was replaced by small round-shaped cells (Figure 1h).

\subsection{Maintenance of Embryogenic Tissue}

The embryogenic tissues were maintained over a long period of time, by serial subcultures, at two-to-three-week intervals, on a fresh DCR proliferation medium supplemented with BA $\left(1 \mathrm{mg} \cdot \mathrm{L}^{-1}\right)$. No auxins were needed for tissue proliferation. On a maintenance medium, the embryogenic tissue remained at the proliferation stage. During the followed growth period of 21 days, fresh and dry mass accumulation gradually increased, but the tested cell lines differed (Figure 2). Cell line A01 showed the maximum fresh mass accumulation after three weeks of proliferation, approximately with a nine-fold increase. Some cell lines (A02 and A07) proliferated intensively, with a seven-fold increase in fresh mass accumulation, while others showed only a three-to-four-fold increase (A06, A10, A23, A30 and A31). The dry mass accumulation displayed a similar pattern and was positively correlated with the fresh mass accumulation (Figure 3).

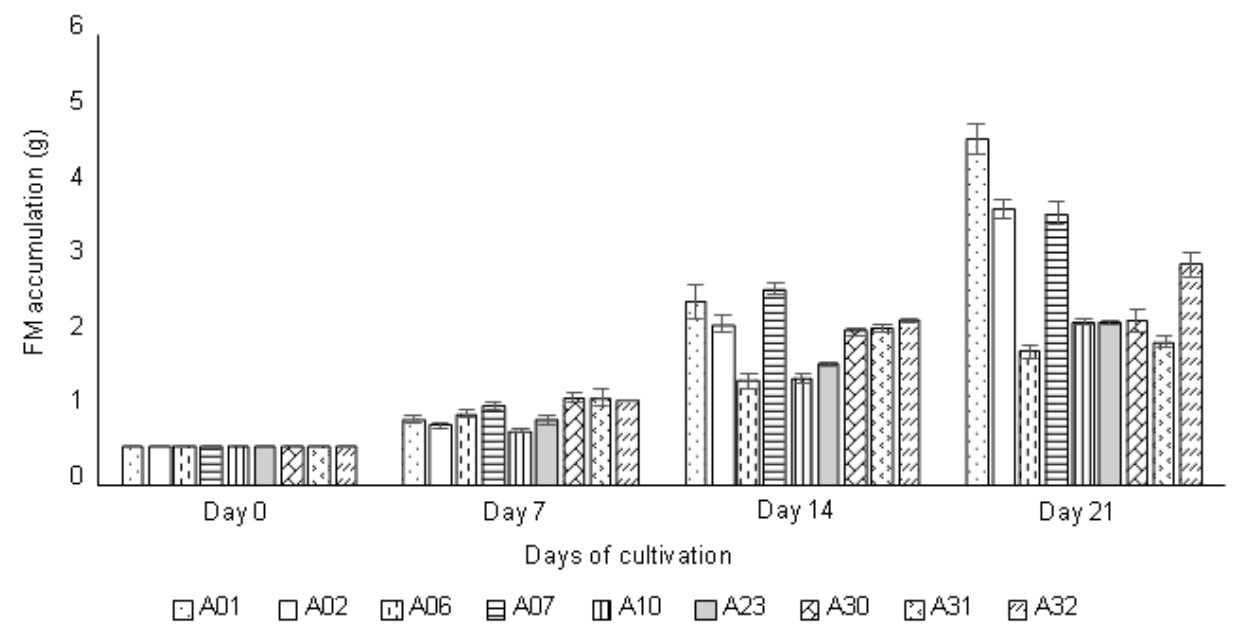

Figure 2. Fresh mass (FM) accumulation (g) in selected cell lines (A01...A32) during the growth cycle; at day 0 , the fresh mass was $0.5 \mathrm{~g}$ for all cell lines $(n=10)$.

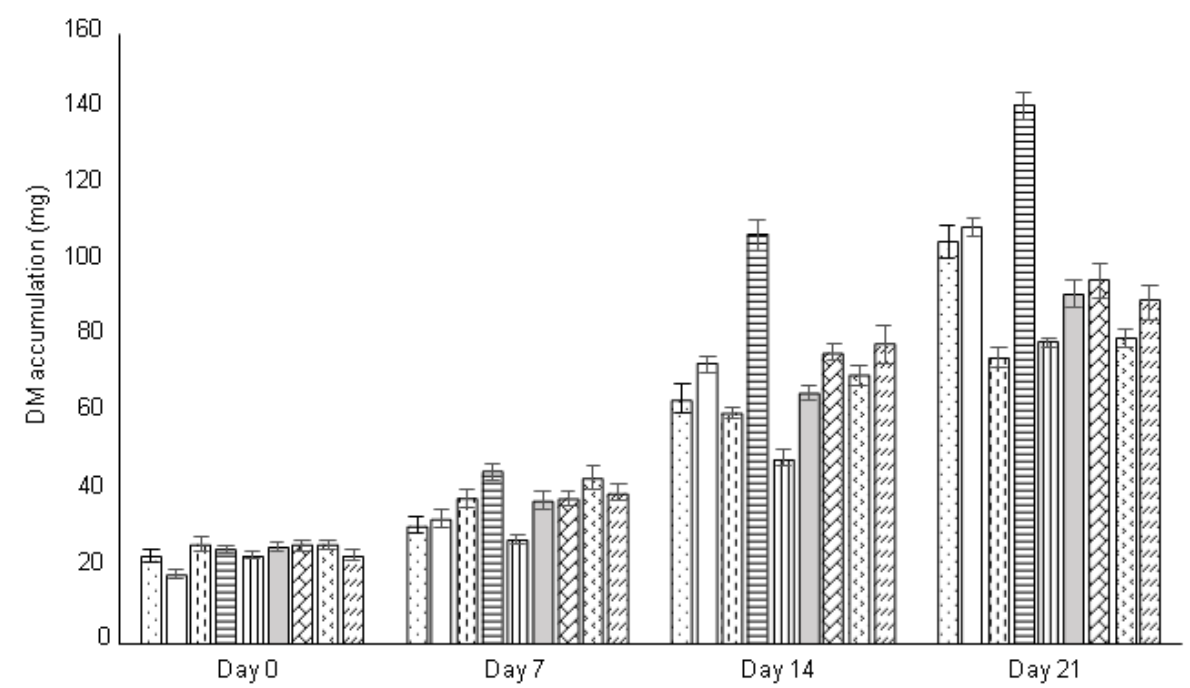

Figure 3. Dry mass (DM) accumulation (mg) in selected cell lines (A01...A32) during the growth cycle $(n=10)$. 
Regular subcultures at two-to-three-week intervals were necessary to maintain vigorously growing tissues. Longer subculture intervals caused progressive tissue browning and necrotization. Occasionally white sectors with a proliferating capacity appeared on the surface of browning cultures. Isolation of such sectors from necrotic tissue and subsequent culture on a proliferation medium resulted in their further growth.

\subsection{Somatic Embryo Maturation}

During the maturation process, the somatic embryos of different cell lines followed similar patterns of development, despite their quantitative differences in somatic embryo production. After plating of the resuspended embryogenic tissue to a maturation medium, tissue regeneration started at days 4-5. After four to five weeks, precotyledonary somatic embryos became visible as structures anchored in embryogenic tissue by huge suspensors and distinguisable embryonic regions (Figure 4a). Following this period, gradually somatic embryos with emerging cotyledons developed (Figure $4 \mathrm{~b}$ ).
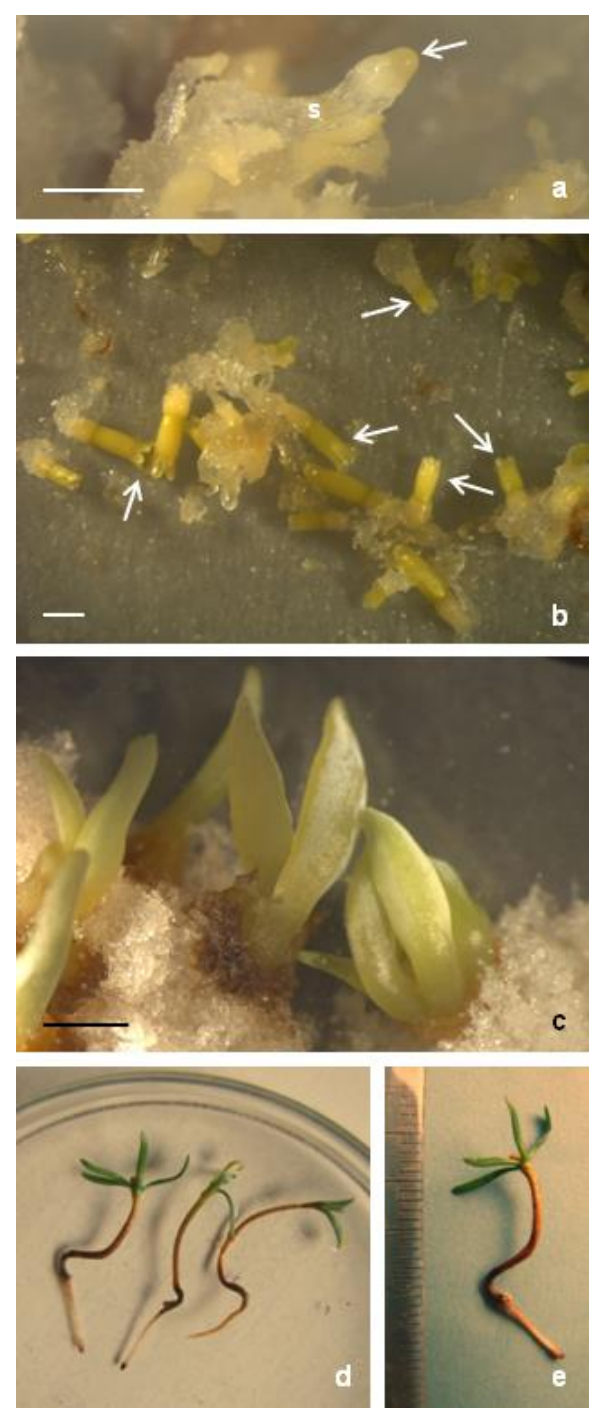

Figure 4. Somatic embryo maturation in Abies alba: (a) precotyledonary somatic embryo with apparent embryonal part (arrow) and suspensor (s) anchored in embryogenic tissue; (b) cotyledonary somatic embryos (arrows) developed on a maturation medium, approximately after eight weeks of cultivation; (c) abnormally developed structures with overproliferated tissue; (d,e) regenerated plantlets (somatic seedlings). Bars: (a,b) $000 \mu \mathrm{m}$; (c) $2000 \mu \mathrm{m}$. 


\subsection{Quantitative Assessment}

At the end of the fifth week of maturation, numerous precotyledonary somatic embryos appeared on the surface of the callus. All of the tested cell lines produced precotyledonary somatic embryos (Stage 2), but significant differences were observed among cell lines (Table 2). Similarly, the cell lines differed in their ability to form fully developed cotyledonary somatic embryos. In the tested cell lines, many precotyledonary somatic embryos stopped their development without cotyledon differentiation. In the most productive cell line (A01), the development of precotyledonary somatic embryos to cotyledonary developmental stage reached $42.93 \%$. A very weak development was achieved in cell line A30, with 6.55\% conversion only. In this cell line, strong proliferation occurred, and the Stage 2 embryos were overgrown by proliferating tissue.

In all the tested cell lines, besides the well-developed somatic embryos, high numbers of abnormally developed structures, characterized by abnormal cotyledons were also present (Figure 4c). The aberrant strucures showed no further development. Moreover, the development of somatic embryos toward the cotyledonary stage (Stage 3) was unsynchronized. Somatic embryo maturation on a medium without PEG-4000 was not satisfactory, showing extreme proliferation of tissue in cell lines A01, A30 and A31, as well as somatic embryos degeneration, at the very early developmental stage, in cell line A32.

Table 2. Somatic embryo (se) maturation and germination in selected embryogenic cell lines of Abies alba Mill. (the number of somatic embryos was calculated per $1 \mathrm{~g}$ of fresh mass).

\begin{tabular}{|c|c|c|c|c|c|}
\hline Cell Line & Precotyledonary Se ${ }^{1}$ & Cotyledonary Se ${ }^{1}$ & $\mathbf{R P}^{2}$ & Germination (\%) & $\mathrm{SE}^{3}$ \\
\hline A01 & $587(45.67)$ & $252(23.30)$ & 49 & $53^{\mathrm{a}}(5.13)$ & 93 \\
\hline A30 & $244(48.17)$ & $16(5.36)$ & & & \\
\hline A31 & $119(36.21)$ & $58(10.22)$ & 32 & $45^{\mathrm{a}}(13.07)$ & 70 \\
\hline A32 & $312(33.54)$ & $101(23.21)$ & 22 & $43^{\mathrm{a}}(3.12)$ & 51 \\
\hline
\end{tabular}

\subsection{Germination}

The partially dessicated somatic embryos were placed horizontally on a germination medium and cultured in darkness for approximately 7 to 10 days. During this period, there was a slight elongation of hypocotyl and cotyledons. Further culture under dimmed light for another 7-10 days followed by culture on full light for another 1-2 weeks resulted in small plantlets with a 1.0-1.5 cm hypocotyl and elongated green cotyledons. The small plantlets were subsequently cultured in Magenta jars in light where they developed further. The lenght of root ranged between $3 \mathrm{~mm}$ and $1 \mathrm{~cm}$ (Figure $1 \mathrm{~d}$,e). Thereafter the somatic seedlings ceased to grow. The germination frequencies were similar in all tested cell lines (Table 2)

\subsection{Cryopreservation}

Cryopreservation of embryogenic tissues with the classical slow cooling method was successful and resulted in tissue regeneration of all tested cell lines, with frequencies between 81.1 and $100 \%$. The differences observed among individual cell lines were statistically insignificant (Figure 5). Tissue regeneration started soon after thawing (four to seven days) and starting the third week of post-thaw culture; all regenerated tissues showed intensive proliferation. 


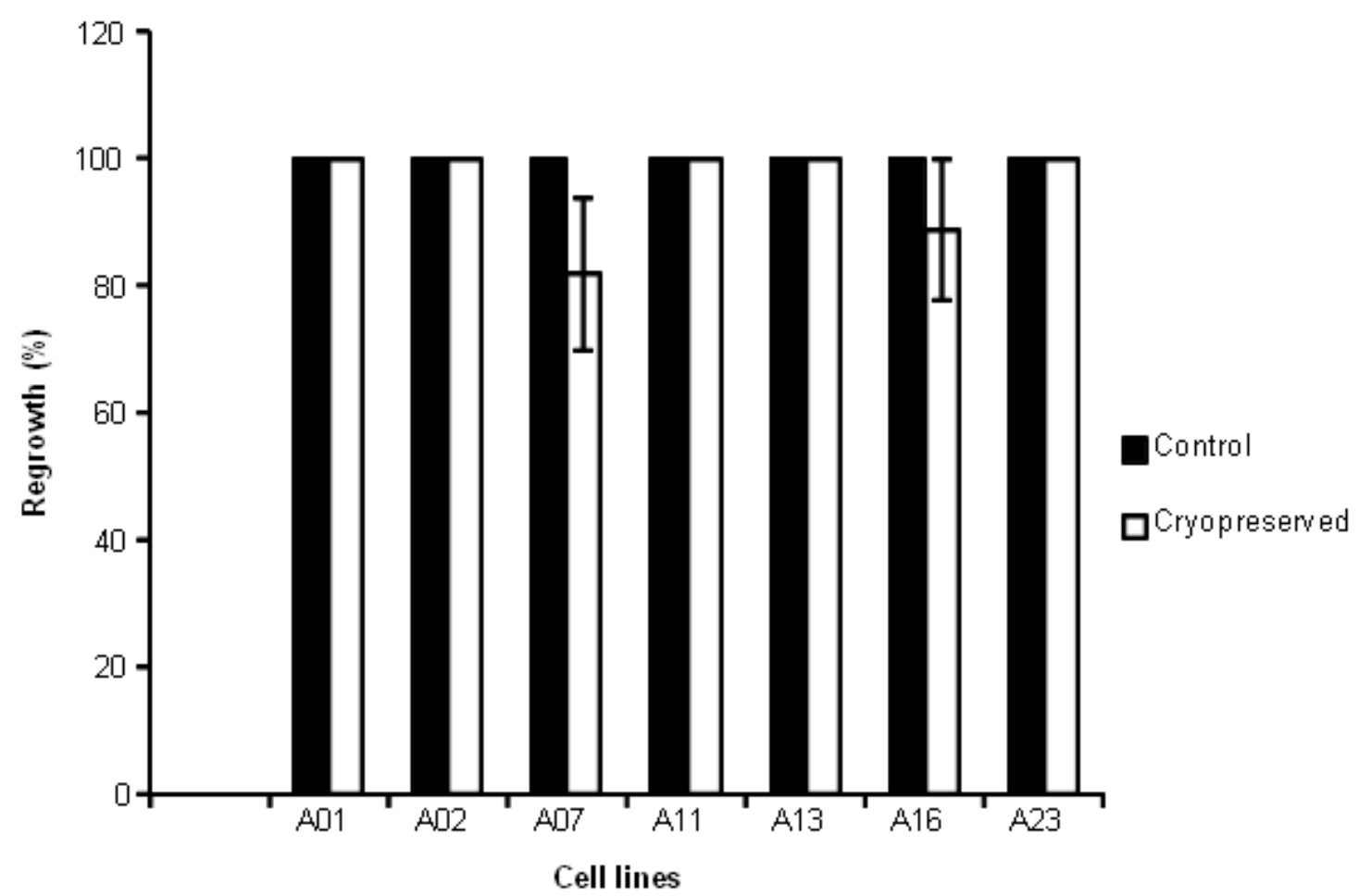

Figure 5. Regrowth (\%) of different cell lines after cryopreservation (comparison to control tissue that was pretreated but not cryopreserved); three repetitions, each containing five Petri dishes; bars indicate standard errors.

\section{Discussion}

The successfull initiation of somatic embryogenesis in conifers depends on several factors, including the explant, exogenous plant growth regulators and basal medium composition $[4,34]$. In our experiments, the embryogenic tissue was initiated from immature zygotic embryos enclosed in the megagametophytes. Megagametophytes containing immature zygotic embryos have been used successfully as explants for the initiation of embryogenic tissues in Abies species or their hybrids $[15,16,21,27,29,35,36]$, but the specific role of the megagametophyte in embryogenic tissue initiation has not been exactly determined. It is hypothesized that the megagametophyte provides nutrients and/or endogenous plant hormones that may be suboptimal in the culture medium [37], or can act as a mechanical barrier protecting the zygotic embryo during the cultivation [38].

In our experiments, the effect of different cytokinins on the initiation of somatic embryogenesis was tested over three consecutive years. Depending on the applied cytokinin and the year, initiation frequencies ranged between 0.83 and $13.33 \%$. For the majority of conifer species, somatic embryogenesis initiation requires the presence of both auxins and cytokinins [4]. For species belonging to the genus Abies, cytokinin as a sole plant-growth regulator was sufficient for both the initiation of embryogenic cultures and the maintenance of initiated tissue $[12,14,39,40]$. The endogenous auxin production might be sufficient [11]. The role of exogenous auxin has been less extensively studied in Abies. Vondrakova et al. [41] showed a positive effect of exogenously applied 2,4-D on Abies alba somatic embryogenesis. The embryogenic tissues growing on a medium supplemented with 2,4-D yielded a higher number of mature somatic embryos, although, during the maturation period, no 2,4-D was needed. In Abies hybrids, embryogenic tissue initiation occurred also on a medium containing 2,4-D combined with BA, but during proliferation, non-embryogenic callus formation was observed [42]. Zancani et al. [43] evaluated the hormone-like effect of fulvic acid (FA) on somatic embryogenesis in Abies cephalonica. It stimulated the proliferation rate at the early growth stage.

In 2013, the initiation frequency reached $8.03 \%$ and is comparable to those obtained by Krajnakova et al. [29] for Abies alba: $5.8 \%$ in total, and 1.7 to $16.6 \%$, depending on sampling date of 
cones, but lower in comparison to the initiation frequencies of $22.5 \%$ obtained by Schuller et al. [27]. Such differences may originate from different experimental conditions applied in different laboratories.

In our experiments, somatic embryo maturation was achieved on a medium containing ABA $\left(10 \mathrm{mg} \cdot \mathrm{L}^{-1}\right)$ combined with PEG-4000 (7.5\%) and 3\% maltose. This medium was chosen based on our previous experiences with Abies hybrids [24,44]. The yield of cotyledonary embryo with developed cotyledons reached 16 to 252 per $g$ of fresh mass inoculum, depending on the cell lines. Most studies on somatic embryo maturation in conifers reported the combination of the hormone ABA and high-molecular-weight osmoticum (PEG). Frequently observed responses to ABA are stimulation of storage reserves accumulation [31], reduction of tissue proliferation [45] and inhibition of cleavage and polyembryony [46]. Proper timing of exposure, as well as the concentration of ABA, significantly improved somatic embryo yield and their quality in loblolly pine. The mRNAs abundance in response to exogenous ABA could be used as a possible expression marker in somatic embryo maturation [47].

The addition of PEG as a non-plasmolysic osmoticum was an important factor in obtaining fully developed cotyledonary somatic embryos in Abies alba. PEG-4000 exerts non-osmotic moisture stress at the cellular level, preventing plasmolysis [48]. In white spruce, the addition of PEG-4000 stimulated storage lipid deposition and increased desiccation tolerance [49]. Storage proteins that were accumulated during maturation of white spruce somatic embryos resembled that of mature zygotic embryos [50]. The timing and concentration of PEG-4000 effect are also important. In Abies nordmanniana, Norgaard [51] reported the optimum PEG-4000 effect in the period of precotyledonary somatic embryo formation. The optimal concentration of PEG-4000 depends on the species, e.g., 7.5\% for white spruce [50], 4\% for the same species referred by Kong and Young [52] or 3.75\% for Picea abies [53]. Tissue overproliferation during somatic embryo maturation in Abies species is a serious problem. In Abies nordmannina, PEG-4000 reduced tissue proliferation [51].

Besides well-developed cotyledonary somatic embryos, abnormal structures with fused cotyledons have also been frequently observed in our study. The abnormal somatic embryo development in conifers may be the result of a disturbed polar auxin transport [54]. The insufficiently developed somatic embryos of Norway spruce were eliminated by low doses of an anti-actin drug, latrunculin B, applied at the beginning of somatic embryo maturation [55].

In Abies alba, the germination was tested after a slight dessication of somatic embryos, and the germination percentages were lower compared to other Abies species. In Abies nordmanniana, different medium compositions for germination of somatic embryos were used [51], and the maximal percentages, around $60 \%$, were obtained on a $\frac{1}{2}$ MS medium, as well as on a medium solidified with agar and supplemented with activated charcoal. The combined effect of sucrose and maltose resulted in $61 \%$ germination and also vigorous planlets development in Abies alba [28]. In both species mentioned, the somatic seedlings were transferred to soil. The growth of somatic seedlings obtained in Abies alba came to a halt seven to eight weeks after germination, probably due to dormant bud formation.

Zoglauer et al. [56] reported 80-90\% conversion of somatic embryos of A. nordmanniana into somatic seedlings, independent of the genotype and with a $90 \%$ survival rate of somatic seedlings under appropriate conditions. Somatic seedlings often go into dormancy, but a cold treatment could break this for the somatic seedlings to start growing again [56].

Cryopreservation has frequently been applied for the long-term maintenance of conifer embryogenic tissues [57-59], including Abies species such as A.nordmanniana [60], A. cephalonica [22,61], A. alba [29] and A. fraseri [21], or Abies hybrids [32,33].

Storage in liquid nitrogen provides several advantages over the long-term in vitro culture on solid media or suspension cultures. Cryopreservation avoids the time-consuming frequent transfers to fresh media and may prevent the decline or complete loss of regeneration capacity of cell lines observed in conifers embryogenesis [62]. The conifer somatic embryos can be stored in liquid nitrogen in their very early developental stage, as bipolar structures, regenerated after storage and used for maturation. The slow-freezing technique was mostly used for conifer embryogenic tissue, including Abies species. Based on our previous experience with Abies hybrids [32,33], this method was also chosen for seven 
cell lines of Abies alba. All tested cell lines recovered at high frequencies: 81.1 to $100 \%$ for individual cell lines. In A. alba, Krajňáková et al. [29] reported that four out of 12 cell lines recovered after cryostorage for six years. In our cryopreserved cell lines of $A$. alba, no significant differences in recovery frequencies among cell lines were recorded, although the cryotolerance in some conifer species was genotype dependent $[56,58]$. In control cell lines that were pretreated but not cryostored, the recovery frequencies reached $100 \%$, indicating the cryoprotectant solutions had no harmful effect on recovery.

\section{Conclusions}

In the presented work, the successful initiation of the economically important conifer species, Abies alba Mill., is described. The embryogenic tissues were initiatied from immature zygotic embryos, and the effect of five types of cytokinins was evaluated, using a DCR medium, in three consecutive years. Althogether, 61 cell lines were obtained. The initiation frequencies ranged from 0.83 to $13.33 \%$, although no statistically significant differences in the effect of the cytokinins in the given year were obtained. On maturation medium with ABA $\left(10 \mathrm{mg} \cdot \mathrm{L}^{-1}\right)$, as well as PEG-4000 (7.5\%), cotyledonary somatic embryos developed, and their germination was terminated by somatic seedling regeneration.

Storage in liquid nitrogen for one year resulted in successful tissue regeneration in seven tested cell lines, reaching regrowth frequencies of 81.1 to $100 \%$. This successful regeneration system for Abies alba via somatic embryogenesis needs further follow-up with the establishment and growth of somatic seedlings under natural conditions. We hypothize that this step could be improved by using a cold treatment, as demonstrated in other conifer species. Owing to the fact that the differerent embryogenic cell lines apparently differ in maturation capacity, a proteomic approach is forseen to study this phenomenon in more detail. The "ageing" effect, as shown in our study on the structural level, needs further physiological and biochemical investigations.

Author Contributions: Conceptualization, T.S., K.K. and J.S.; methodology, T.S., K.K., B.P. and J.S.; analysis T.S., B.P. and R.S.; data interpretation, T.S., K.K., J.S. and R.S.; original draft preparation, T.S., K.K., B.P. and J.S. All authors have read and agreed to the published version of the manuscript.

Funding: This work was supported by funding from Slovak Grant Agency VEGA proj. No. 2/0056/18.

Acknowledgments: BP gratefully acknowledge the Directorate-general Development Cooperation and Humanitarian, Belgium (DGD) for financial support. Many thanks also to Yu-Chun Liao for critical proof reading the text.

Conflicts of Interest: The authors declare no conflict of interest.

\section{References}

1. Hakman, I.; Fowke, L.C.; von Arnold, S.; Eriksson, T. The development of somatic embryos in tissue cultures initiated from immature embryos of Picea abies (Norway spruce). Plant Sci. 1985, 38, 53-59. [CrossRef]

2. Chalupa, V. Somatic embryogenesis and plant regeneration from cultured immature and mature embryos of Picea abies (L.). Karst. Comm. Inst. Czechoslov. 1985, 14, 57-63.

3. Lelu-Walter, M.A.; Thompson, D.; Harvengt, L.; Sanchez, L.; Toribio, M.; Paques, L. Somatic embryogenesis in forestry with a focus on Europe: State-of-the-art, benefits, challenges and future direction. Tree Genet. Genomes 2013, 9, 883-899. [CrossRef]

4. Klimaszewska, K.; Hargreaves, C.; Lelu-Walter, M.A.; Trontin, J.F. Advances in conifer somatic embryogenesis since year 2000. In In Vitro Embryogenesis in Higher Plants, Methods in Molecular Biology 1359; Germana, M.A., Lambardi, M., Eds.; Springer Science+Business Media: New York, NY, USA, 2016; pp. 131-166.

5. Egertsdotter, U. Plant physiological and genetical aspects of the somatic embryogenesis process in conifers. Scand. J. Res. 2019, 34, 360-369. [CrossRef]

6. Gupta, P.K.; Hartle, J. Mass clonal propagation of conifer trees via somatic embryogenesis: Scale up and automation. In Proceedings of the Production and Establishment of Micropropagated Plants, Book of Abstracts, 6th International ISHS Symposium, Grand Hotel Londra, Sanremo, Italy, 19-24 April 2005; p. 59. 
7. Mamun, N.H.A.; Aidun, C.K.; Egertsdotter, U. Improved and synchronized maturation of Norway spruce (Picea abies (L.) Karst.) somatic embryos in temporary immersion bioreactors. Vitr. Cell. Dev. Biol. Plant 2018, 54, 612-620. [CrossRef]

8. Välimäki, S.; Paavilainen, L.; Tikkinen, M.; Salonen, F.; Varis, S.; Aronen, T. Production of Norway spruce embryos in a temporary immersion system (TIS). In Vitro Cell. Develop. Biol. Plant 2020, 56, 430-439.

9. Saravitz, C.H.; Blazich, F.A.; Amerson, H.V. Histology of adventitious bud development on cotyledons and hypocotyls of Fraser fir. J. Am. Soc. Hortic. Sci. 1993, 118, 163-167. [CrossRef]

10. Zoglauer, K.; Reuther, G. Somatische Embryogenese bei der Weistanne. Mitt. Landesanst. Wald Forstwirtsch. 1996, 11, 123-135.

11. Vooková, B.; Gajdošová, A. Induction of adventitious buds on the cotyledons of Abies concolor $\times$ Abies grandis hybrid seedlings. Biol. Plant. 1992, 34, 23-29. [CrossRef]

12. Nörgaard, J.V.; Krogstrup, P. Cytokinin induced somatic embryogenesis from immature embryos of Abies nordmanniana. Plant Cell Rep. 1991, 9, 509-513.

13. Kvaalen, H.; Daehlen, O.G.; Rognstad, A.T.; Gronstad, B.; Egertsdotter, U. Somatic embryogenesis for plant production of Abies lasiocarpa. Can. J. Res. 2005, 35, 1053-1060. [CrossRef]

14. Krajňáková, J.; Gömöry, D.; Häggman, H. Somatic embryogenesis in Greek fir. Can. J. Res. 2008, 38, 760-769. [CrossRef]

15. Gajdošová, A.; Vooková, B.; Kormut'ák, A.; Libiaková, G.; Doležel, J. Induction, protein composition and DNA ploidy level of embryogenic calli of silver fir and its hybrids. Biol. Plant. 1995, 37, 169-176. [CrossRef]

16. Salajova, T.; Jasik, J.; Kormutak, A.; Salaj, J.; Hakman, I. Embryogenic culture initiation and somatic embryo development in hybrid firs (Abies alba $\times$ Abies cephalonica and Abies alba $\times$ Abies numidica). Plant Cell Rep. 1996, 15, 527-530.

17. Vooková, B.; Kormut'ák, A. Plantlet regeneration in Abies cilicica Carr. and Abies cilicica $\times$ Abies nordmanniana hybrid via somatic embryogenesis. Turk. J. Bot. 2003, 27, 71-76.

18. Korecký, J.; Vitámvás, J. Somatic embryogenesis of the hybrid Abies cilicica $\times$ Abies cephalonica. J. Sci. 2011, 57, 401-408. [CrossRef]

19. Nörgaard, J.V.; Krogstrup, P. Somatic embryogenesis in Abies species. In Somatic Embryogenesis in Woody Plants, Volume 3 Gymnosperms; Jain, S.M., Gupta, P.K., Newton, R.J., Eds.; Kluwer Academic Publishers: Dordrecht, The Netherlands, 1995; pp. 341-355.

20. Rajbhandari, N.; Stomp, A.M. Embryogenic callus induction in Fraser fir. Hort. Sci. 1997, 32, 737-738. [CrossRef]

21. Pullman, G.S.; Olson, K.; Fischer, T.; Egertsdotter, U.; Frampton, J.; Bucalo, K. Fraser fir somatic embryogenesis: High frequency initiation, maintenance, embryo development, germination and cryopreservation. New For. 2016, 47, 453-480. [CrossRef]

22. Misson, J.-P.; Druart, P.; Panis, B.; Watillon, B. Contribution to the study of the maintenance of somatic embryos of Abies nordmanniana L.K.: Culture media and cryopreservation method. Propag. Ornament. Plants 2006, 6, 17-23.

23. Guevin, T.; Kirby, E.G. Induction of embryogenesis in cultured mature zygotic embryos of Abies fraseri (Pursh) Poir. Plant Cell Tissue Organ Cult. 1997, 49, 219-222. [CrossRef]

24. Salaj, T.; Salaj, J. Somatic embryo formation on mature Abies alba $\times$ Abies cephalonica zygotic embryo explants. Biol. Plant 2003, 47, 7-11. [CrossRef]

25. Erdelsky, K.; Barancok, P. Cultivating embryos of silver fir (Abies alba MILL.) in vitro. Acta Facult Rerum Naturalium Univ. Comeniana Physiol. Plant 1986, 23, 25-29.

26. Gebhardt, K.; Weisberger, H.; Fröhlich, H.J. In vitro germination and production of embryogenic callus from liquid suspension cultures of Abies alba. In Proceedings of the Poster at Intern. Conifer Tissue Culture Working Group 4th Meeting, Saskatoon, Canada, 8-12 August 1988.

27. Schuller, A.; Reuther, G.; Geier, T. Somatic embryogenesis from seed explants of Abies alba. Plant Cell Tissue Organ Cult. 1989, 17, 53-58.

28. Hristoforoglu, K.; Schmidt, J.; Bolharnordenkampf, H. Development and germination of Abies alba somatic embryos. Plant Cell Tissue Organ Cult. 1995, 40, 277-283. [CrossRef]

29. Krajňáková, J.; Bertolini, A.; Gömöry, D.; Vianello, A.; Häggman, H. Initiation, long-term cryopreservation, and recovery of Abies alba Mill. embryogenic cell line. In Vitro Cell. Develop. Biol. Plant 2013, 49, 560-571. 
30. Gupta, P.K.; Durzan, D.J. Shoot multiplication from mature trees of Douglas-fir (Pseudotsuga menziesii) and sugar pine (Pinus-lambertiana). Plant Cell Rep. 1985, 4, 177-179. [CrossRef]

31. Von Arnold, S.; Hakman, I. Regulation of somatic embryo development in Picea abies by abscisic acid. J. Plant Physiol. 1988, 132, 164-169. [CrossRef]

32. Salaj, T.; Matusikova, I.; Panis, B.; Swennen, R.; Salaj, J. Recovery and characterisation of hybrid firs (Abies alba $\times$ A.cephalonica, Abies alba $\times$ A. numidica) embryogenic tissues after cryopreservation. CryoLetters 2010, 31, 206-217.

33. Salaj, T.; Matusova, R.; Panis, B.; Swennen, R.; Salaj, J. Tissue regeneration of Abies embryogenic cell lines after 1 year storage in liquid nitrogen. Biologia 2016, 71, 93-99. [CrossRef]

34. Salaj, T.; Matusova, R.; Salaj, J. Conifer somatic embryogenesis an efficient plant regeneration system for theoretical studies and mass propagation. Dendrobiology 2015, 74, 69-76. [CrossRef]

35. Szczygiel, K.; Kowalczyk, J. Somatic embryogenesis of Silver fir (Abies alba Mill.) Polish provenances. Acta Hortic. 2001, 560, 509-512. [CrossRef]

36. Vooková, B.; Kormut'ák, A. Improved plantlet regeneration from open-pollinated families of Abies alba trees of Dobroč primeval forest and adjoing managed stand via somatic embryogenesis. Biologia 2009, 64, 1136-1140. [CrossRef]

37. Becwar, M.R.; Pullman, G.S. Somatic embryogenesis in loblolly pine (Pinus taeda L.). In Somatic Embryogenesis in Woody Plants; Volume 3 Gymnosperms; Jain, S.M., Gupta, P.K., Newton, R.J., Eds.; Kluwer Academic Publishers: Dordrecht, The Netherlands, 1995; pp. 287-301.

38. Salajova, T.; Salaj, J.; Jasik, J.; Kormutak, A. Somatic embryogenesis in Pinus nigra Arn. In Somatic Embryogenesis in Woody Plants; Volume 3 Gymnosperms; Jain, S.M., Gupta, P.K., Newton, R.J., Eds.; Kluwer Academic Publishers: Dordrecht, The Netherlands, 1999; pp. 207-220.

39. Vooková, B.; Gajdošová, A.; Matúšová, R. Somatic embryogenesis in Abies alba $\times$ Abies alba and Abies alba $\times$ Abies nordmanniana hybrids. Biol. Plant. 1998, 40, 523-530.

40. Kim, Y.W.; Newton, R.; Frampton, J.; Han, K.-H. Embryogenic tissue initiation and somatic embryogenesis in Fraser fir (Abies fraseri (Pusch) Poir.). In Vitro Cell. Dev. Biol. Plant 2009, 45, 400-406. [CrossRef]

41. Vondráková, Z.; Eliášová, K.; Fischerová, L.; Vágner, M. The role of auxins in somatic embryogenesis of Abies alba. Central Europ. J. Biol. 2011, 6, 587-596.

42. Salajova, T.; Salaj, J. Somatic embryogenesis and plantlet regeneration from cotyledon explants isolated from emblings and seedlings of hybrid firs. J. Plant Physiol. 2001, 158, 747-755. [CrossRef]

43. Zancani, M.; Bertolini, A.; Petrussa, E.; Krajňáková, J.; Piccolo, A.; Spaccini, R.; Vianello, A. Fulvic acid affects proliferation and maturation phases in Abies cephalonica embryogenic cells. J. Plant Physiol. 2011, 168, 1226-1233. [CrossRef]

44. Salaj, T.; Matusova, R.; Salaj, J. The effect of carbohydrates and polyethylene glycol on somatic embryo maturation in hybrid fir Abies alba $\times$ Abies numidica. Acta Biol. Cracov. Bot. 2004, 46, 159-167.

45. Stasolla, C.; Kong, L.S.; Yeung, E.C.; Thorpe, T.A. Maturation of somatic embryos in conifers: Morphogenesis, physiology, biochemistry, and molecular biology. In Vitro Cell. Dev. Biol. Plant 2002, 38, 93-105. [CrossRef]

46. Gupta, P.K.; Pullman, G.; Timmis, R.; Kreitinger, M.; Carlson, W.C.; Grob, J.; Welty, E. Forestry in the 21th century. The biotechnology of somatic embryogenesis. Biotechnology 1993, 11, 454-459.

47. Vales, T.; Feng, X.; Ge, L.; Xu, N.; Cairney, J.; Pullman, G.S.; Peter, G.F. Improved somatic embryo maturation in loblolly pine by monitoring ABA-responsive gene expression. Plant Cell Rep. 2007, 26, 133-143. [CrossRef] [PubMed]

48. Attree, S.M.; Fowke, L.C. Embryogeny of gymnosperms: Advances in synthetic seed technology of conifers. Plant Cell Tissue Organ Cult. 1993, 35, 1-35. [CrossRef]

49. Attree, S.M.; Pomeroy, M.K.; Fowke, L.C. Manipulation of conditions for the culture of somatic embryos of white spruce for improved triacylglycerol biosynthesis and desiccation. Planta 1992, 187, 395-404. [CrossRef] [PubMed]

50. Misra, S.; Attree, S.M.; Leal, I.; Fowke, L.C. Effect of abscisic acid, osmoticum and desiccation on synthesis of storage proteins during the development of white spruce somatic embryos. Ann. Bot. 1993, 71, 11-22. [CrossRef]

51. Nörgaard, J.V. Somatic embryo maturation and plant regeneration in Abies nordmanniana. Plant Sci. 1997, 124, 211-221. [CrossRef] 
52. Kong, L.; Yeung, E.C. Effect of silver nitrate and polyethylene glycol on white spruce (Picea glauca) somatic embryo development: Enhancing cotyledonary embryo formation and endogenous ABA content. Physiol. Plant 1995, 93, 298-304. [CrossRef]

53. Svobodova, H.; Albrechtova, J.; Kumstyrova, L.; Lipavska, H.; Vagner, M.; Vondrakova, Z. Somatic embryogenesis in Norway spruce: Anatomical study of embryo development and influence of polyethylene glycol on maturation process. Plant Physiol. Biochem. 1999, 37, 209-221. [CrossRef]

54. Abrahamsson, M.; Valladares, S.; Larsson, E.; Clapham, D.; von Arnold, S. Patterning during somatic embryogenesis in Scots pine in relation to polar auxin transport and programmed cell death. Plant Cell Tissue Organ Cult. 2012, 109, 391-400. [CrossRef]

55. Schwarzerová, K.; Vondráková, Z.; Fischer, L.; Boríková, P.; Bellinvia, E.; Eliášová, K.; Havelková, L.; Fišerová, J.; Vágner, M.; Opatrný, Z. The role of actin isoforms in somatic embryogenesis in Norway spruce. BMC Plant Biol. 2010, 10, 89. [CrossRef]

56. Zoglauer, K.; Aurich, C.; Uehre, P.; Herrmann, S. Somatic embryogenesis in Abies nordmanniana: Present status and future application. In Proceedings of the S1-2 (Oral Presentation), 2nd International Conf IUFRO Working Party 2.09.02, Brno, Czech Republic, 25-28 June 2012; pp. S1-S2.

57. Häggman, H.M.; Ryynänen, L.A.; Aronen, T.; Krajnakova, J. Cryopreservation of embryogenic cultures of Scots pine. Plant Cell Tissue Organ Cult. 1998, 54, 45-53. [CrossRef]

58. Fraga, H.P.F.; Vieira, L.N.; Puttkammer, C.; da Silva, J.M.; dos Anjos, K.G.; Oliveira, E.M.; Guerra, M.P. High-efficiency cryopreservation of Araucaria angustifolia (Bertol.) Kuntze embryogenic cultures: Ultrastructural characterisation and morpho-physiological features. Plant Cell Tissue Organ Cult. 2016, 124, 307-318. [CrossRef]

59. Nunes, S.; Marum, L.; Farinha, N.; Pereira, V.T.; Almeida, T.; Dias, M.C.; Santos, C. Plant regeneration from ploidy-stable cryopreserved embryogenic lines of the hybrid Pinus elliottii $\times$ P. caribaea. Ind. Crop. Prod. 2017, 105, 215-224. [CrossRef]

60. Nörgaard, J.V.; Baldursson, S.; Krogstrup, P. Genotypic differences in the ability of embryogenic Abies nordmanniana culture to survive cryopreservation. Silvae Gen. 1993, 42, 93-97.

61. Aronen, T.; Krajnakova, J.; Häggman, H.; Ryynänen, L.A. Genetic fidelity of cryopreserved embryogenic cultures of open-pollinated Abies cephalonica. Plant Sci. 1999, 142, 163-172. [CrossRef]

62. Klimaszewska, K.; Noceda, C.; Pelletier, G.; Label, P.; Rodriguez, R.; Lelu-Walter, M.-A. Biological characterization of young and aged embryogenic cultures of Pinus pinaster (Ait.). In Vitro Cell. Dev. Biol. Plant 2009, 45, 20-33. [CrossRef]

Publisher's Note: MDPI stays neutral with regard to jurisdictional claims in published maps and institutional affiliations.

(C) 2020 by the authors. Licensee MDPI, Basel, Switzerland. This article is an open access article distributed under the terms and conditions of the Creative Commons Attribution (CC BY) license (http://creativecommons.org/licenses/by/4.0/). 